Check for updates

Bogotá

Cite this as: $B M J$ 2022;376:0230 http://dx.doi.org/10.1136/bmj.0230 Published: 26 January 2022

\title{
Covid-19: Cuba will request WHO approval for homegrown vaccine
}

\section{Luke Taylor}

Cuban health officials have said that they will apply for World Health Organization approval for one of the country's homegrown covid-19 vaccines, as they announced that they had secured funding to produce 200 million vaccine doses for low income countries.

Cuba's health regulator (CECMED) has approved the use of three of the country's homegrown vaccines, which are exported to four countries, but none has been yet been approved by WHO. ${ }^{1}$ That should change this year, said Rolando Pérez Rodríguez, director of science and innovation at Cuba's state run pharmaceutical conglomerate, BioCubaFarma.

"We have formally requested the prequalification of one vaccine: Abdala,” Rodriguez told a press conference in Havana on 25 January. "We are in the final review of the documents, and it should be sent in the following days to the WHO."

The application for WHO approval of a second Cuban vaccine, Soberana 2, should be sent in the coming weeks and is also expected to gain authorisation for use this year, said Dagmar García Rivera at the Finlay Institute of Vaccines in Havana.

\section{Vaccine candidates}

Cuba has regained control of the record rate of covid-19 infections seen last summer. Its rollout of Abdala, Soberana 2, and a booster vaccine, Soberana Plus, has kept the more infectious omicron variant under control after it reported 861 new daily infections per million population in August 2021, the highest in the world. ${ }^{2}$ On 24 January, by contrast, Cuba reported 284 new cases per day per million people.

Abdala is $92.3 \%$ effective against symptomatic infection after three doses, and Soberana 2 is $92.4 \%$ effective after two doses and an additional dose of Soberana Plus, non-peer-reviewed studies have shown. ${ }^{34}$ Cuba has other vaccine candidates in trials, including Soberana 1 and Mambisa-an intranasal vaccine-as well as one that targets the nascent omicron variant. ${ }^{5}$

The island nation has fully vaccinated $86 \%$ of its population and administered 2.97 doses for every person, more than anywhere else in the world. ${ }^{6}$

\section{Solidarity}

Cuba exports its vaccines to Iran, Nicaragua, Venezuela, and Vietnam and is in discussion with more than 15 countries, most of which are low income nations, said Rodríguez. It recently donated covid-19 vaccines to Syria and to St Vincent and the Grenadines and is sharing knowledge and technical know-how with other countries to help them manufacture the vaccines locally.

Rodríguez said, "We are open to any proposal that implies a greater impact of our vaccines on the world
... [Lack of WHO approval] has not been an obstacle for countries interested in the Cuban vaccines." He added that the vaccines had been sold at a "price of solidarity" comparable to the Covax scheme, which distributes vaccines to low and middle income countries. The country's manufacturing capacity allows it to produce around 120 million vaccine doses a year. ${ }^{7}$

However, WHO approval is a requisite for Covax vaccines, which has prevented Cuban shots from being administered through the WHO co-led mechanism. "Perhaps when the authorisation is there, that will facilitate or accelerate distribution," said Rodríguez.

Preliminary studies show that the vaccines hold up well against omicron, said Ileana Morales Suárez, director of science and technology innovation at Cuba's Ministry of Public Health.

"Those vaccinated with Soberana and Abdala have high percentages of seroconversion against the omicron variant," she said. The results, which should be published this week, were "very encouraging and favourable."

1 World Health Organization. Status of covid-19 vaccines within WHO EUL/PQ evaluation process. Guidance document. 23 Dec 2021. https://extranet.who.int/pqweb/sites/default/files/documents/Status_COVID_VAX_23Dec2021.pdf

2 Our World In Data. Global covid-19 infections data. Jan 2022. https://ourworldindata.org/explorers/coronavirus-data-explorer?tab=table\&zoomToS election=true\&time=earliest.2021-08-01\&facet=none\&pickerSort=asc\&pick erMetric=new_cases_smoothed_per_million\&hideControls=true\&Interval=New+per+day\&Relative+to+Population=true \&country $=\sim$ CUB\&Metric $=$ Confirmed+cases\&Color+by+test+positivity=false

3 Cuban Ministry of Foreign Affairs. Abdala vaccine: 100\% efficacy against severe disease and death in its phase III trial. 17 Jul 2021. http://misiones. minrex.gob.cu/es/articulo/vacuna-abdala-100-eficacia-ante-la-enfermedadsevera-y-la-muerte-en-su-ensayo-fase-iii

4 Toledo-Romani ME, Garcia-Carmenate M, Valenzuela Silva C, et al. Efficacy and safety of SOBERANA 02, a COVID-19 conjugate vaccine in heterologous three-dose combination. medRxiv [preprint] 2021.10.31.21265703. doi: 10.1101/2021.10.31.21265703. https://www.medrxiv.org/content/10.1101/2021.10.31.21265703v2

5 Taylor L. Cuba's home-grown vaccines have massively cut covid-19 cases New Scientist2021 Dec 23. https://www.newscientist.com/article/2303121 cubas-home-grown-vaccines-have-massively-cut-covid-19-cases/

6 Holder J. Covid vaccinations tracker. New York Times 2022 (updated 26 Jan). https://www.nytimes.com/interactive/2021/world/covid-vaccinationstracker.html

7 Progressive International. Cuba pledges "lifesaving package" of covid-19 vaccine support to Global South at Progressive International briefing. 25 Jan 2022. https://progressive.international/wire/2022-01-25-cuba-pledges lifesaving-package-of-covid-19-vaccine-support-to-global-south-at-progressive-international-briefing/en

This article is made freely available for personal use in accordance with BMJ's website terms and conditions for the duration of the covid-19 pandemic or until otherwise determined by BMJ. You may download and print the article for any lawful, non-commercial purpose (including text and data mining) provided that all copyright notices and trade marks are retained. 